\title{
Adsorption of vanadium(V) polymers on ferrihydrite and hematite
}

\author{
COlton J. VesseY ${ }^{\mathrm{a}}$, Michael P. SchMidT ${ }^{\mathrm{c}}$, MojtaBA \\ ABDOLAHNEZHAD ${ }^{\mathrm{b}}$, DEREK PEAK ${ }^{\mathrm{c}}$, MATTHEW B.J. \\ LINDSAY ${ }^{\mathrm{b} *}$

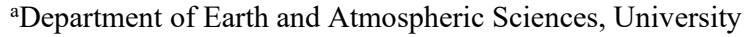 \\ of Alberta, Edmonton, AB, T6G 2E3, Canada \\ ${ }^{b}$ Department of Geological Sciences, University of \\ Saskatchewan, Saskatoon, SK, S7N 5E2, Canada \\ ${ }^{\mathrm{c}}$ Department of Soil Scinces, University of Saskatchewan, \\ Saskatoon, SK, S7N 2V3 \\ (*correspondence: matt.lindsay@usask.ca)
}

Vanadium (V) is widely used in industrial processes (e.g., catalysis), manufacturing (e.g., steel making), and as a proxy for studying biogeochemical processes over geologic time [1]. However, anthroprogenic releases of this potentially hazardous transition metal have increased in recent decades [2]. While several studies have observed uptake of mononuclear $\mathrm{V}$ species (i.e., $\mathrm{H}_{\mathrm{x}} \mathrm{VO}_{4}{ }^{(3-\mathrm{x})-}{ }_{(\mathrm{aq})}$ ) by iron (oxyhydr)oxides [3], reactions involving polynuclear species $\left(\left[\mathrm{H}_{\mathrm{x}} \mathrm{V}_{2} \mathrm{O}_{7}\right]^{(4-\mathrm{x})^{-}}, \mathrm{V}_{4} \mathrm{O}_{12}{ }^{4-}\right.$, and $\left.\left[\mathrm{H}_{\mathrm{x}} \mathrm{V}_{10} \mathrm{O}_{28}\right]^{(6-\mathrm{x})-}\right)$ have not yet been characterized. We examine surface comlextion of (poly)vanadate species on ferrihydrite $\left[5 \mathrm{Fe}_{2} \mathrm{O}_{3} \cdot 9 \mathrm{H}_{2} \mathrm{O}\right]$ and hematite $\left[\alpha-\mathrm{Fe}_{2} \mathrm{O}_{3}\right]$ using in situ attenuated total reflectance Fourier transform infrared spectroscopy (ATR-FTIR).

We collected the ATR-FTIR spectra on an Invenio-R FTIR spectrometer using a Bruker Platinum ATR with a single-bounce $\mathrm{ZnSe} /$ diamond internal reflective element (IRE) with a $45^{\circ}$ incidence angle. Ferrihydrite and hematite were drop cast $\left(10 \mathrm{~g} \mathrm{~L}^{-1}\right)$ onto the IRE and equilibrated with $0.05 \mathrm{M} \mathrm{NaCl}$ background electrolyte. Adsorption isotherms were then produced by equilibrating $\mathrm{V}(\mathrm{V})$ solutions $(50,100$, $250,500,750,1000,3000$ and $5000 \mu \mathrm{M}$ ) with ferrihydrite or hematite films under constant flow at $\mathrm{pH} 3,4,5$, and 6.

Our results reveal $\mathrm{pH}$ - and concentration-dependent adsorption of mononuclear and polynuclear $\mathrm{V}$ species at both ferrihydrite and hematite surfaces. Adsorbed polynuclear species were prevalent at $[\mathrm{V}]_{\mathrm{T}}>250 \mu \mathrm{M}$. Ferrihdyrite had a limited capacity to adsorb polyvanadate species at $\mathrm{pH} 5$ and 6 , whereas surface polymers were evident at all experimental $\mathrm{pH}$ values during adorption onto hematite. Our findings indicate the importance in considering the sequestration and fate of $\mathrm{V}(\mathrm{V})$ polynuclear species in the environment.

[1] Huang et al. (2016) Chem. Geol., 417, 68-89. [2] Watt et al. (2018) Environ. Sci. Technol., 52, 11973-11974. [3] Brinza et al. (2015) Cryst. Growth Des., 15, 4768-4780. 